\title{
CA125 II Assay
}

National Cancer Institute

\section{Source}

National Cancer Institute. CA125 II Assay. NCI Thesaurus. Code C120015.

A second generation radioimmunoassay to measure serum levels of CA-125. 